Jurnal Health Sains: p-ISSN: 2723-4339 e-ISSN: 2548-1398

Vol. 2, No. 3, Maret 2021

\title{
PENGARUH PENGHASILAN DAN GAYA HIDUP TERHADAP KEJADIAN HIPERTENSI PADA NELAYAN DI KOTA MEDAN
}

Kiki Rismadi, Albiner Siagian dan Fazidah Agustina Siregar

Universitas Sumatera Utara (USU) Medan Sumatera Utara, Indonesia

Email: kikyrismadi89@gmail.com, albiner_sgn@yahoo.com dan fazidah65@yahoo.com

\begin{tabular}{l}
\hline ARTIKEL INFO \\
\hline Tanggal diterima: 5 Maret 2021 \\
Tanggal direvisi: 15 Maret 2021 \\
Tanggal diterima: 25 Maret \\
2021
\end{tabular}

Keywords:

income; lifestyle; hypertension

\section{ABSTRACT}

The purpose of this study is to analyze the influence of social factors (age, education, income and working period) and lifestyle (diet, smoking, drinking coffee and sleep duration) on the incidence of hypertension in fishermen in Medan. Research is observational analytics with the design of control case studies. The subject consists of cases and controls with a ratio of 1:1. The sample consisted of 53 cases and 53 controls. The case sample is that the fisherman suffers from hypertension and the control sample is another fisherman who does not suffer from hypertension. Bivariate test results with simple logistic regression obtained significant influences are variable age $(p=0.000)$, education $(p=0.008)$, income $(p=0.000)$, diet $(p=0.000)$ and smoking $(p=0.002)$ against hypertension incidence in fishermen in Medan. As for variables that have no significant effect are drinking coffee $(p=0.606)$ and sleep duration $(p=0.127)$. Based on the results of multivariate tests with multiple logistic regression dominant factors that significantly affect hypertension in fishermen in Medan is diet $(O R=6,972$ $p=0.001)$. It is recommended to fishermen to avoid foods that are at risk of hypertension, stop smoking and adequate wives, improved health education efforts in efforts to prevent hypertension, especially related to diet and smoking habits in fishermen

\section{ABSTRAK}

Tujuan penelitian ini adalah untuk menganalisa pengaruh faktor sosial (umur, pendidikan, penghasilan dan masa bekerja) dan gaya hidup (pola makan, merokok, minum kopi dan durasi tidur) terhadap kejadian hipertensi terhadap kejadian hipertensi pada nelayan di Kota Medan. Penelitian bersifat analitik observasional dengan rancangan studi kasus kontrol. Subjek terdiri dari kasus dan kontrol dengan perbandingan 1:1. Sampel terdiri dari 53 kasus dan 53 kontrol. Sampel kasus adalah nelayan menderita hipertensi dan sampel kontrol adalah nelayan lainnya yang tidak menderita hipertensi. Hasil uji bivariat dengan simple logistic regression diperoleh pengaruh yang signifikan adalah variabel umur $(p=0,000)$, pendidikan $(\mathrm{p}=0,008)$, penghasilan $(\mathrm{p}=0,000)$, pola makan 
Kata Kunci:

penghasilan; gaya hidup; hipertensi $(\mathrm{p}=0,000)$ dan merokok $(\mathrm{p}=0,002)$ terhadap kejadian hipertensi pada nelayan di Kota Medan. Sedangkan untuk variabel yang tidak berpengaruh signifikan adalah minum kopi $(\mathrm{p}=0,606)$ dan durasi tidur $(\mathrm{p}=0,127)$. Berdasarkan hasil uji multivariat dengan multiple logistic regression faktor dominan yang berpengaruh secara signifikan terhadap hipertensi pada nelayan di Kota Medan adalah pola makan $(\mathrm{OR}=6,972 \mathrm{p}=0,001)$. Disarankan kepada nelayan agar menghindari makanan yang berisiko hipertensi, berhenti merokok dan istrirahat yang cukup, upaya edukasi kesehatan lebih ditingkatkan dalam upaya pencegahan hipertensi terutama terkait pola makan dan kebiasaan merokok pada nelayan.

Coresponden Author:

Email: kikyrismadi89@gmail.com Artikel dengan akses terbuka dibawah lisensi

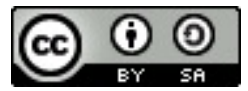

\section{Pendahuluan}

Penyakit tidak menular (PTM) merupakan permasalahan kesehatan masyakarat yang menjadi penyebab utama kematian secara global. Seiring dengan bertambahnya populasi di dunia maka kematian akibat PTM akan semakin meningkat. Di tahun 2016 kematian akibat PTM terjadi sekitar 57 juta (71\%) dimana 85 persen diantaranya terjadi di negara-negara dengan berpenghasilan rendah dan menengah dan 12 persen terjadi di negara dengan berpenghasilan tinggi. PTM secara global dipengaruhi oleh berbagai faktor diantaranya penggunaan tembakau, aktifitas fisik, konsumsi alkohol dan pola makan yang tidak sehat (Organization, 2015).

Prevalensi penyakit tidak menular di Indonesia selama tahun 2013-2018 mengalami peningkatan yaitu diantaranya terjadi pada penyakit hipertensi $(34,1 \%)$, diabetes $(8,1 \%)$, gagal ginjal kronik $(3,8 \%)$ kanker $(1,8 \%)$ dan stroke $(10,9 \%)$ (Riskesdas, 2018). Hipertensi adalah salah satu penyakit tidak menular yang terjadi akibat adanya peningkatan tekanan darah diatas 140/90 mmHg dengan dua kali pengukuran selang waktu lima menit dalam keadaan tenang/istrirahat (Kemenkes, 2014). Prevalensi hipertensi di Indonesia semakin meningkat dan masih banyaknya pendeita yang belum mendapatkan pengobatan secara teratur yang mengakibatkan timbulnya berbagai penyakit komplikasi diantaranya yaitu stroke, serangan jantung dan jantung koroner. Pada tahun 2015 terlihat berdasarkan data Pembiayaan Jaminan Kesehatan Nasional terdapat 1,3 juta orang $(0,8 \%)$ peserta Jaminan Kesehatan Nasional (JKN) memperoleh pelayanan untuk penyakit tidak menular, dengan total anggaran sebanyak 13,6 triliun rupiah dimana 11,59 persen akibat penyakit jantung dan 1,95 persen akibat stroke (Kemenkes RI, 2016).

Berdasakan data Riskesdas 2018 prevalensi hipertensi nasional pada penduduk yang berusia $\geq 18$ tahun yaitu 34,1 persen dengan prevalensi hipertensi tertinggi di Kalimantan Selatan sebanyak 44,1 persen sedangkan prevalensi hipertensi terendah di Maluku Utara sebanyak 22,2 persen, sementara di provinsi Sumatera Utara terdapat sekitar 29,9 persen penduduk yang mengalami hipertensi (Kemenkes RI, 2016). 
Berdasarkan data dari Dinas Kesehatan Kota Medan, sepuluh penyakit terbanyak pada rawat jalan dimana hipertensi merupakan penyakit terbesar kedua di kota Medan yaitu sebesar 16,53 persen di tahun 2016 (Medan, 2016).

Nelayan adalah pekerjaan sektor informal yang menjadi mayoritas bagi para masyarakat pesisir yang dalam aktfitas sosial ekonominya berkaitan dengan sumber daya wilayah pesisir dan laut. Nelayan memiliki kebiasaan mengkonsumsi makanan dengan natrium tinggi, mengasinkan makanan yang berasal dari laut sebagai proses pengawetan alami hasil laut, dan mengonsumsi hewan laut dengan kandungan kadar kolesterol lebih tinggi (Rusliafa et al., 2014) . Dalam penelitian (Fatma, 2010) menunjukan adanya hubungan antara kebiasaan nelayan dalam konsumsi natrium (OR 2,62), konsumsi kalium (OR 2,51), konsumsi kopi (OR 3,65) dan kebiasaan merokok (OR 3,13) dengan kejadian hipertensi pada nelayan.

Nelayan memiliki kebiasaan istirahat dan pola tidur dimana yang mengharuskan nelayan bekerja pada malam hari untuk melaut dan menangkap ikan, hal tersebut menjadi salah satu pola hidup pada nelayan yang tidak sehat. Pola tidur pada nelayan adalah salah satu faktor resiko hipertensi yang dapat dikendalikan, selain dengan mengurangi kebiasaan buruk seperti merokok dan mengonsumsi makanan yang beresiko hipertensi namun melalui optimalisasi kualitas dan kuantitas tidur. Resiko hipertensi pada orang yang memiliki pola tidur yang buruk 9,02 kali lebih besar dibandingkan dengan pola tidur yang baik (Roshifanni, 2016).

Selain itu pendidikan dan status sosial ekonomi akan memengaruhi pengetahuan dan kemampuan nelayan mengenai pencegahan dan mencari pengobatan sedini mungkin terhadap gejala hipertensi (Hussain et al., 2016). Dari segi sosial ekonomis yang dapat dilihat dari pendapatan masyarakat nelayan memiliki penghasilan yang bergantung pada kegiatan penangkapan hasil laut, pendapatan nelayan yang tidak tetap dikarenakan penghasilan yang diperoleh bergantung pada musim, cuaca dan tingkat kebutuhan konsumsi pasar terhadap ikan. Kebanyakan nelayan masih memiliki tingkat pendapatan rendah dan tidak menentu sepanjang tahun, pendapatan yang diperoleh nelayan digunakan untuk memenuhi kebutuhan yang sebagian besarnya digunakan untuk belanja harian (Mahazan et al., 2015). Penelitian (Husain \& Rohmah, 2020) menyatakan ada hubungan antara pendidikan dan sosial ekonomi $(p<0,05)$ terhadap kejadian hipertensi pada pria berusia dewasa muda, dimana berpengaruh dalam memeriksakan diri ke pelayanan kesehatan sedini mungkin terhadap gejala dan memberikan pengobatan secara rutin terhadap hipertensi.

Jumlah penduduk yang memiliki pekerjaan sebagai nelayan terbanyak di Kota Medan adalah Kecamatan Medan Belawan dimana secara letak demografi Kecamatan Medan Belawan terletak di kawasan pesisir pantai yang menjadi tempat sumber mata pencaharian nelayan. Penduduk dengan mata pencaharian nelayan terbanyak di Medan Belawan adalah di Kelurahan Bagan Deli yaitu 1.484 jiwa. Berdasarkan survei pendahuluan di Puskesmas Pembantu Kelurahan Bagan Deli Kecamatan Medan Belawan yang secara demografi mata pencaharian terbesar adalah nelayan dan buruh lepas pengolahan hasil laut, jumlah kunjungan untuk hipertensi merupakan penyakit terbesar kedua selama tahun 2019 mencapai 2.879 orang. Dari hasil pemeriksaan tekanan darah dan melakukan wawancara dengan kuesioner kepada 30 orang nelayan berusia $<50$ tahun didapatkan 24 orang $(80 \%)$ diantaranya terdeteksi memiliki tekanan darah $\geq 140 / 90 \mathrm{mmHg}$ dengan memiliki kebiasaan diantaranya merokok sebanyak 22 orang $(91,6 \%)$, minum kopi sebanyak 28 orang (93\%), minum 
minuman berenergi/soda 4 orang $(13 \%)$, makan tidak teratur sebanyak 28 orang $(93 \%)$, makan makanan berlemak dan gorengan sebanyak 28 orang $(93 \%)$, tidak memeriksakan rutin kesehatan sebanyak 30 orang $(100 \%)$, tidak memiliki jaminan/asuransi kesehatan sebanyak 30 orang $(100 \%)$.

Berdasarkan hasil survei pendahuluan tersebut dapat disimpulkan bahwa masih tingginya angka kejadian hipertensi pada nelayan di Kota Medan serta belum optimalnya penelitian mengenai determinan yang menyebabkan terjadinya hipertensi pada nelayan di daerah Kota Medan mendorong peneliti untuk menganalisis pengaruh penghasilan dan gaya hidup yang terhadap hipertensi pada nelayan di kota Medan.

\section{Metode Penelitian}

Jenis penelitian yang digunakan dalam penelitian ini adalah observasional analitik dengan design studi kasus kontrol untuk menganalisis penghasilan dan gaya hidup (pola makan, merokok, minum kopi dan durasi tidur) kejadian hipertensi pada nelayan dengan cara membandingkan kelompok kasus dan kontrol. Design kasus kontrol, merupakan penelitian epidemiologis analitik observasional yang menelaah hubungan antara efek (penyakit atau kondisi kesehatan) tertentu dengan faktor risiko tertentu. Desain penelitian kasus kontrol dapat dipergunakan untuk menilai berapa besarkah peran faktor risiko dalam kejadian penyakit (cause-effect relationship) (Sastroasmoro \& Ismael, 2011).

Penelitian ini dilaksanakan di Kelurahan Bagan Deli Kecamatan Medan Belawan Kota Medan dengan alasan adalah daerah tersebut terletak memiliki kawasan pesisir dan pantai yang memiliki jumlah penduduk dengan mata pencaharian sebagai nelayan terbanyak di Kota Medan yaitu 1.484 jiwa (Eberhardt et al., 2017). Penelitian ini dilaksanakan dimulai dari bulan Januari 2020 sampai dengan September 2020.

Populasi kasus pada penelitian ini adalah seluruh nelayan yang pernah didiagnosis hipertensi oleh petugas kesehatan dan minum obat hipertensi. Populasi kontrol adalah pada penelitian ini adalah nelayan yang mempunyai tekanan darah $<140 / 90$ $\mathrm{mmHg}$ atau normal $120 \mathrm{mmHg}$ atau tidak pernah didiagnosis hipertensi oleh petugas kesehatan dan tidak minum obat hipertensi serta bertempat tinggal berada di sekitar kasus. Sampel kasus adalah adalah nelayan yang mempunyai tekanan darah $\geq 140 / 90$ $\mathrm{mmHg}$ atau pernah diagnosis hipertensi oleh petugas kesehatan dan minum obat hipertensi. Sampel kontrol adalah nelayan yang tidak mempunyai tekanan darah $\geq 140 / 90 \mathrm{mmHg}$ atau tidak pernah didiagnosis hipertensi oleh petugas kesehatan dan tidak minum obat hipertensi serta bertempat tinggal berada di sekitar kasus.

Jumlah keseluruhan sampel adalah 106 orang dengan perbandingan kasus dan kontrol adalah 1:1, antara kasus dan kontrol dilakukan unmatching. Dalam penelitian ini sampel penelitian adalah sampel yang telah memenuhi kriteria inklusi sedangkan kriteria eksklusi adalah sampel yang tidak termasuk dalam penelitian ini

Teknik pengambilan sampel dilakukan secara purposive sampling. Sumber data dalam penelitian ini adalah berupa data primer yang dilakukan dengan teknik wawancara secara terstruktur dengan menggunakan kuesioner dan sumber data sekunder yang meliputi jumlah penduduk berdasakan pekerjaan yaitu nelayan diperoleh melalui dokumen dari instansi terkait (Statistik, 2019) serta penelusuran kepustakaan yang berkaitan dengan penelitian yang sifatnya ilmiah dan relevan dengan tujuan dan permasalahan penelitian.

Metode analisis data berupa analisa univariat yang digunakan untuk memperoleh gambaran pada masing-masing variabel 
independen yang meliputi umur, pendidikan, pendapatan dan gaya hidup (pola makan merokok, minum kopi dan durasi tidur) dan variabel dependen yaitu kejadian hipertensi. Data yang dalam bentuk kategori akan disajikan dalam bentuk distribusi frekuensi dengan bentuk ukuran persentase. Analisis bivariat dilakukan dengan uji statistik simple logistik regresion dan analisis multivariat pada penelitian ini menggunakan uji Regresi Logistik Berganda (Multiple Regression Logistic).

\section{Hasil dan Pembahasan}

Penelitian dilakukan untuk mengetahui pengaruh faktor penghasilan dan gaya hidup terhadap kejadian hipertensi pada nelayan di Kota Medan.

\section{a. Analisis Univariat}

\section{Tabel 1}

Distribusi Umur, Pendidikan, penghasilan Responden Hipertensi dan Tidak Hipertensi Pada Nelayan di Kota Medan

\begin{tabular}{|c|c|c|c|c|c|}
\hline \multirow[t]{2}{*}{ Gaya Hidup } & \multicolumn{2}{|c|}{ Kasus } & \multicolumn{2}{|c|}{ Kontrol } & \multirow{2}{*}{\begin{tabular}{|c|} 
Total \\
$\%$
\end{tabular}} \\
\hline & $\mathrm{N}=53$ & $\%$ & $\mathrm{~N}=53 \%$ & $\%$ & \\
\hline \multicolumn{6}{|l|}{ Pola Makan } \\
\hline$\overline{B e r e s i k o ~}$ & 47 & 88.7 & 28 & 47 & $\begin{array}{l}\mathbf{8 8 , 7} \\
\end{array}$ \\
\hline Tidak Beresiko & 6 & 11,3 & 25 & 6 & 11,3 \\
\hline \multicolumn{6}{|l|}{ Merokok } \\
\hline$\overline{Y a}$ & 50 & 94,3 & 36 & 50 & 94,3 \\
\hline Tidak & 3 & 5,7 & 17 & 3 & 5,7 \\
\hline \multicolumn{6}{|l|}{ Minum Kopi } \\
\hline$\overline{\mathbf{Y a}}$ & 43 & 81,1 & 45 & 43 & 81,1 \\
\hline Tidak & 10 & 18,9 & 8 & 10 & 18,9 \\
\hline \multicolumn{6}{|l|}{ Durasi Tidur } \\
\hline$<8 \mathrm{Jam} /$ Hari & 47 & 88,7 & 41 & 47 & $\begin{array}{ll}88,7 \\
\end{array}$ \\
\hline$\geq 8 \mathrm{Jam} /$ Hari & 6 & 11,3 & 12 & 6 & 11,3 \\
\hline
\end{tabular}

Berdasarkan tabel 1 di atas diperoleh responden dalam penelitian ini adalah jumlah respoden usia $<40$ tahun dan $\geq 40$ tahun memiliki jumlah yang sama Namun pada kasus mayoritas terdapat pada umur $\geq 40$. Hal ini menggambarkan bahwa seiring bertambahnya usia resiko untuk terkena hipertensi semakin meningkat. Berdasarkan pendidikan mayoritas nelayan baik pada kelompok kasus sebanyak 43 orang $(81,1 \%)$ dan kontrol sebanyak 30 orang $(50,6 \%)$ memiliki pendidikan rendah yaitu dengan jumlah mayoritas memiliki tingkat pendidikan akhir adalah Sekolah Menengah Pertama (SMP).

Dilihat dari penghasilan nelayan pada kelompok kasus yang memiliki penghasilan sesuai UMK sebanyak 42 orang $(79,2 \%)$ dan yang tidak UMK sebanyak 11 orang $(20,8 \%)$ dan pada kelompok kontrol yang memiliki penghasilan sesuai UMK sebanyak 16 orang $(30,2 \%)$ dan tidak UMK sebanyak 37 orang $(69,8)$.

Berdasartkan tabel 2 dapat diperoleh informasi bahwa dari hasil penelitian dari 53 orang yang menderita hipertensi sebanyak 47 orang $(88,7 \%)$ memiliki kebiasaan makan beresiko hipertensi karena sering mengonsumsi makanan yang tinggi garam seperti ikan asin, cumi asin dan kecap asin, makanan bersantan seperti ikan gulai, ayam gulai dan sayur gulai, makanan berlemak atau digoreng seperti ikan goreng, aneka gorengan, makanan berprotein tinggi seperti daging, telur dan jeroan, makanan berpenyedap tinggi seperti lontong, mie ayam, mie bakso, mie sop dan mie goreng, makanan berkarbonhidrat seperti roti.Pada kelompok kontrol sebanyak 28 orang $(52,8$ $\%)$. Sedangkan responden yang pola makan yang tidak beresiko (jarang makan makanan beresiko) pada kelompok kasus sebanyak 6 orang $(11,3 \%)$ dan pada kelompok kontrol sebanyak 25 orang $(47,2 \%)$.

Tabel 2

Distribusi Gaya Hidup (Pola Makan, Merokok, Minum Kopi dan Durasi Tidur) Responden Hipertensi dan Tidak Hipertensi Pada Nelayan di Kota Medan

\begin{tabular}{lcccccc}
\hline \multirow{2}{*}{$\begin{array}{l}\text { Karakteristik } \\
\text { Responden }\end{array}$} & \multicolumn{2}{c}{ Kasus } & \multicolumn{2}{c}{ Kontrol } & \multicolumn{2}{c}{ Total } \\
\cline { 2 - 7 } & $\mathbf{N}=\mathbf{5 3}$ & $\%$ & $\mathrm{~N}=53$ & $\%$ & $\mathrm{~N}=53$ & $\%$ \\
\hline Umur & & & & & & \\
\hline$\geq 40$ Tahun & 39 & $\mathbf{7 3 , 6}$ & $\mathbf{1 4}$ & $\mathbf{2 6 , 4}$ & $\mathbf{5 3}$ & $\mathbf{5 0 , 0}$ \\
\hline$<40$ Tahun & $\mathbf{1 4}$ & $\mathbf{2 6 , 4}$ & $\mathbf{3 9}$ & $\mathbf{7 3 , 6}$ & $\mathbf{5 3}$ & $\mathbf{5 0 , 0}$ \\
\hline Pendidikan & & & & & & \\
\hline Rendah & 43 & $\mathbf{8 1 , 1}$ & $\mathbf{3 0}$ & $\mathbf{5 6 , 6}$ & $\mathbf{7 3}$ & $\mathbf{6 8 , 9}$ \\
\hline Menengah & $\mathbf{1 4}$ & $\mathbf{1 8 , 9}$ & $\mathbf{2 3}$ & $\mathbf{4 3 , 4}$ & $\mathbf{3 3}$ & $\mathbf{3 1 , 1}$ \\
\hline Penghasilan & & & & & & \\
\hline Tidak UMK & $\mathbf{1 1}$ & $\mathbf{2 0 , 8}$ & $\mathbf{3 7}$ & $\mathbf{6 9 , 8}$ & $\mathbf{4 8}$ & $\mathbf{4 5 , 3}$ \\
\hline UMK & 42 & $\mathbf{7 9 , 2}$ & 16 & $\mathbf{3 0 , 2}$ & $\mathbf{5 8}$ & $\mathbf{5 4 , 7}$ \\
\hline
\end{tabular}


Berdasarkan tabel 2 diperoleh informasi bahwa responden pada kelompok kasus yang merokok sebanyak 50 orang $(94,3 \%)$ dan pada kelompok kontrol sebanyak 36 orang $(67,9 \%)$. Sedangkan responden yang tidak merokok pada kelompok kasus sebanyak 3 orang $(5,7 \%)$ dan pada kelompok kontrol sebanyak 17 orang $(32,1 \%)$. Responden yang merokok mayoritas telah memiliki kebiasaan merokok selama 10-20 tahun dengan jumlah batang rokok adalah 10-20 batang/harinya serta memilih jenis rokok filter yang dikonsumsi setiap harinya.

Berdasarkan tabel 2 diperoleh informasi bahwa responden pada kelompok kasus yang minum kopi sebanyak 43 orang $(81,1 \%)$ dan pada kelompok kontrol sebanyak 45 orang $(84,9 \%)$. Sedangkan responden yang tidak minum kopi pada kelompok kasus sebanyak 10 orang $(18,9 \%)$ dan pada kelompok kontrol sebanyak 8 orang (15,1\%). Responden yang minum kopi mayoritas memiliki kebiasaan minum kopi selama 5-10 tahun dengan jumlah gelas kopi yaitu 3-4 gelas kopi/harinya yang dikonsumsi sebanyak tiga kali dalam seharinya.

Berdasarkan tabel 2 diperoleh informasi bahwa responden pada kelompok kasus yang memiliki durasi tidur $<8 \mathrm{jam} /$ hari sebanyak 47 orang $(88,7 \%)$ dan pada kelompok kontrol sebanyak 41 orang $(77,4 \%)$. Sedangkan responden yang memililki durasi tidur $\geq 8$ jam/hari pada kelompok kasus sebanyak 6 orang $(11,3 \%)$ dan pada kelompok kontrol sebanyak 12 orang $(22,6 \%)$. Durasi tidur yang dimiliki oleh responden dalam hal ini nelayan dipengaruhi dengan jam kerja dimiliki nelayan dimana mayoritas nelayan memiliki jam tidur yaitu tidur pada pukul tiga pagi dan bangun pada pukul sepuluh pagi dan tidur pada pukul sepuluh malam dan bangun pada pukul empat pagi.

\section{b. Hasil Bivariat}

Analisis menggunakan uji Simple Logistic Regression dengan perhitungan CI 95\% untuk mengetahui dan menguji variabel independen dalam penelitian ini adalah penghasilan dan gaya hidup (pola makan, merokok, minum kopi dan durasi tidur) memiliki hubungan dengan variabel dependen yaitukejadian hipertensi.

\section{Tabel 3}

Hasil Analisis Bivariat Variabel Penghasilan dan Gaya Hidup (Pola Makan, Merokok, Minum Kopi dan Durasi Tidur) Terhadap Kejadian Hipertensi pada Nelayan di

\begin{tabular}{|c|c|c|}
\hline \multicolumn{3}{|c|}{ Kota Medan } \\
\hline Variabel Independen & OR $(95 \% \mathrm{CI})$ & $\mathbf{P}$ \\
\hline Penghasilan & $\begin{array}{c}8,830 \\
(3,641-21,410)\end{array}$ & 0,000 \\
\hline Pola Makan & $\begin{array}{c}6,994 \\
(2,145-28,879)\end{array}$ & 0,000 \\
\hline Merokok & $\begin{array}{c}7,870 \\
(2,145-28,879)\end{array}$ & 0,002 \\
\hline Minum Kopi & $\begin{array}{c}1,308 \\
(0,472-3,626)\end{array}$ & 0,606 \\
\hline Durasi Tidur & $\begin{array}{c}2,293 \\
(0,790-6,656)\end{array}$ & 0,129 \\
\hline
\end{tabular}

Berdasarkan tabel 3 hasil analisis bivariat diperoleh bahwa variabel penghasilan, pola makan dan merokok secara signifikan berhubungan dengan kejadian hipertensi $(p<0,05)$ artinya variabel penghasilan, pola makan dan merokok merupakan faktor yang berpengaruh terhadap hipertensi sedangkan variabel minum kopi dan durasi tidur secara signifikan tidak berhubungan dengan kejadian hipertensi artinya variabel minum kopi dan durasi bukan faktor/tidak berpengaruh terhadap kejadian hipertensi pada nelayan di Kota Medan.

\section{c. Analisis Multivariat}

Analisis multivariat dilakukan untuk melihat hubungan variabel 
independen yang dominan berpengaruh dengan variabel dependen secara bersama-sama dengan menggunakan uji regresi logistik ganda (multiple logistic regression) hal ini berguna memperoleh model yang terdiri dari beberapa variabel dependen dimana dalam peneltian ini yaitu kejadian hipertensi ada nelayan di Kota Medan. Varibel independen yaang dijadikan kandidat dalam multiple logistic regression ini adalah variabel yang diperoleh dari hasil analisa bivariat (simple logistic regression).

Tabel 4

Hasil Analisis Multivariat Tahap

Satu Variabel Penghasilan dan Gaya

Hidup (Pola Makan, Merokok, dan

Durasi Tidur) terhadap Kejadian

Hipertensi Pada Nelayan di Kota

Medan

\begin{tabular}{lccccc}
\hline \multirow{1}{*}{$\begin{array}{l}\text { Variabel } \\
\text { Independen }\end{array}$} & $\mathrm{B}$ & Sig. & OR & \multicolumn{2}{c}{$95 \%$ C.I } \\
\cline { 5 - 6 } & & & & Lower & Upper \\
\hline Penghasilan & $\mathbf{1 , 9 3 9}$ & $\mathbf{0 , 0 0 0}$ & $\mathbf{6 , 9 5 3}$ & $\mathbf{2 , 5 4 7}$ & $\mathbf{1 9 , 9 8 0}$ \\
\hline Pola Makan & $\mathbf{2 , 0 3 3}$ & $\mathbf{0 , 0 0 1}$ & $\mathbf{7 , 6 3 7}$ & $\mathbf{2 , 2 3 9}$ & $\mathbf{2 6 , 0 4 9}$ \\
\hline Merokok & $\mathbf{1 , 5 7 0}$ & $\mathbf{0 , 0 3 7}$ & $\mathbf{4 , 8 0 7}$ & $\mathbf{1 , 0 9 7}$ & $\mathbf{2 1 , 0 7 0}$ \\
\hline $\begin{array}{l}\text { Durasi } \\
\text { Tidur }\end{array}$ & $\mathbf{0 , 3 0 5}$ & $\mathbf{0 , 6 6 6}$ & $\mathbf{0 , 7 3 7}$ & $\mathbf{0 , 1 8 4}$ & $\mathbf{2 , 9 4 9}$ \\
\hline
\end{tabular}

Dari tabel 4 diperoleh nilai sinifikansi dari durasi tidur sebesar $\mathrm{p}=0,666 \quad(\mathrm{p}>0,05) \quad$ maka tahap selanjutnya variabel durasi tidur dikeluarkan dari variabel independent dan dilakukan analisis multivariat tahap berikutnya.

\section{Tabel 5}

Hasil Analisis Multivariat Tahap

Akhir Variabel Penghasilan dan

Gaya Hidup (Pola Makan dan

Merokok) terhadap Kejadian

Hipertensi Pada Nelayan di Kota

Medan

\begin{tabular}{|c|c|c|c|c|c|}
\hline \multirow{2}{*}{$\begin{array}{c}\text { Variabel } \\
\text { Independen }\end{array}$} & \multirow[t]{2}{*}{ B } & \multirow[t]{2}{*}{ Sig. } & \multirow[t]{2}{*}{ OR } & \multicolumn{2}{|c|}{$95 \%$ C.I } \\
\hline & & & & & pper \\
\hline Penghasilan & 1,903 & 0,000 & 6,703 & 2,500 & 17,976 \\
\hline Pola Makan & 1,942 & 0,001 & 6,972 & 2,223 & 21,863 \\
\hline Merokok & 1,571 & 0,037 & 4,812 & 1,099 & 21,079 \\
\hline
\end{tabular}

Hasil akhir analisis multivariat dapat diketahui bahwa variabel umur $(\mathrm{p}=0,000)$, penghasilan $(\mathrm{p}=0,001)$, pola makan $(p=0,000)$ dan merokok $(\mathrm{p}=0,020)$ paling berhubungan dengan kejadian hipertensi. Faktor risiko tertinggi adalah pola makan dengan nilai OR 15,068, hal ini juga berarti yaitu variabel pola makan yang paling dominan memengaruhi terjadinya kejadian hipertensi dengan nilai OR sebesar 15,068 (95\%CI: 3,333-68,113). Risiko terjadinya hipertensi pada nelayan dengan pola makan yang berisiko meningkat 15,068 kali lebih besar dibandingkan nelayan yang pola makannya tidak berisiko.

Hasil penelitian ini diperoleh bahwa penghasilan berhubungan signifikan dengan kejadian hipertensi pada nelayan di Kota Medan dengan nilai OR sebesar 8,830 (95\%CI 3,641$21,410 p=0,000)$. Tingkat penghasilan berkaitan dengan jumlah yang diterima oleh seseorang baik dalam akumulasi hitungan hari, minggu, bulan atau tahun yang menunjukan status sosial ekonomi seseorang, dalam hal ini nelayan sebagai responden mayoritas memiliki penghasilan yang tidak UMK yang berpengaruh signifikan terhadap kejadian hipertensi. Rendahnya penghasilan yang diterima oleh seseorang dapat memengaruhi pola konsumsi dan gaya hidup terhadap kejadian hipertensi, keseringan konsumsi makanan instant dan diasinkan pada nelayan dan merokok.

Hasil wawancara diperoleh bahwa pada kelompok kasus mayoritas memiliki penghasilan yang UMK sedangkan pada kelompok kontrol memiliki penghasilan yang tidak UMK. Penghasilan yang cukup dimiliki oleh nelayan sebagai kasus yang menderita hipertensi memengaruhi dalam 
pemilihan jenis dan jumlah bahan makanan yang memiliki kandungan berisiko tinggi terhadap kejadian hipertensi seperti makanan yang tinggi akan lemak dan kolesterol seperti cumi, ayam, udang yang diolah dengan kuah santan sementara kelompok kontrol yang memiliki penghasilan yang tidak UMK memiliki keterbatasan dalam mencukupi kebutuhan hidup terutama dalam pemilihan makanan sehingga dalam mencukupi kebutuhan asupan makanan nelayan memamanfaatkan hasil tangkapan yang telah diawetkan seprti pengasinan agar tahan dan awet serta dapat dikonsumsi setiap saat.

Penghasilan yang rendah pula dapat memengaruhi pemilihan untuk memeriksakan kesehatannya ke fasilitas kesehatan, penderita hipertensi yang tidak memiliki keluhan sehingga masih dapat melakukan aktifitas seharihari tanpa terganggu dengan penyakitnya lebih memilih tidak melakukan pemeriksaan kesehatan secara rutin dan berkala karena menganggap penyakitnya belum mengancam jiwanya, hal tersebut berhubungan dengan persepsi sehat dan sakit (Notoatmodjo, 2012).

Penelitian ini sejalan dengan penelitian (Ningsih \& Kurniawan, 2019) yang dilakukan ada hubungan antara penghasilan dengan kejadian hipertensi $\quad(\mathrm{OR}=3,817 \quad \mathrm{P}=0,000)$, penghasilan seseorang memengaruhi pola makan dan konsumsi makanan yang disediakan, kecil kemungkinan untuk seseorang yang berpenghasilan rendah menyajikan makanan beragam setiap harinya. Semakin tinggi tingkat penghasilan seseorang maka semakin baik sarana dan fasilitas yang akan didaptkannya seperti diantaranya makanan dan pelayanan kesehatan.
Pola makan erat kaitannya dengan frekuensi makan seseorang dan jenis makanan yang dikonsumsi. Frekuensi berlebihan akan mengakibatkan kegemukan yang merupakan faktor pemicu timbulnya infeksi. Selain itu, asupan garam dan lemak yang berlebihan akan menyebabkan hipertensi.

Hasil penelitian menunjukan bahwa pola makan berhubungan signifikan dengan kejadian hipertensi pada nelayan di Kota Medan dengan nilai OR sebesar 15,068 (95\%CI 3,333$15,068 p=0,000)$. Hasil wawancara yang dilakukan kepada kelompok kasus sebanyak 47 orang $(88,7)$ adalah sering mengonsumsi sebagian besar makanan yang beresiko terhadap kejadian hipertensi yaitu makanan yang tinggi garam seperti ikan asin, cumi asin dan kecap asin, makanan bersantan seperti ikan gulai, ayam gulai dan sayur gulai, makanan berlemak atau digoreng seperti ikan goreng, aneka gorengan, makanan berprotein tinggi seperti daging, telur dan jeroan, makanan berpenyedap tinggi seperti lontong, mie ayam, mie bakso, mie sop dan mie goreng, makanan berkarbonhidrat seperti roti. Sedangkan pada kelompok kontrol sebesar 28 orang $(52,8 \%)$ sering mengkonsumsi hanya sebagian dari jenis makanan yang beresiko terhadap kejadian hipertensi yaitu mie bakso, mie sop, dan mie instan, makanan bersantan seperti ikan gulai, ayam gulai dan sayur gula. Frekuensi konsumsi bahan makanan yang berisiko terhadap kejadian hipertensi baik pada kasus ataupun kontrol adalah tiga kali dalam seminggu hingga satu kali sehari.

Saat bekerja di laut nelayan membawa bahan makanan praktis dan instan sebagai stok bahan makanannya 
dimana bahan makanan tersebut adalah makanan berisiko terhadap kejadian hipertensi seperti makanan yang diasinkan, makanan bersantan dan makanan instant dengan berpenyedap. Akan tetapi, kebiasaan konsumsi makanan berisiko tersebut menjadi kebiasaan makan bukan hanya dikonsumsi saat melaut namun pada saat tidak bekerja di laut sehingga hal tesebut menjadi salah satu resiko kejadian hipertensi. Selain itu penghasilan yang tidak menetap dan bergantung pada jumlah tangkapan yang dihasilkan menjadi salah satu yang berpengaruh terhadap pola makan, saat nelayan memiliki penghasilan yang lumayan banyak para nelayan memilih makanan yang tinggi lemak, kolesterol dan berpenyedap seperti olahan daging, ayam , cumi dan udang yang diolah dengan kuah santan dan pada saat penghasilan nelayan sedikit nelayan memilih mengonsumsi hasil tangkap yang tidak laku terjual dan telah diasinkan seperti ikan dan udang asin sebagai lauk dalam keseharian konsumsi.

Penelitian ini sejalan dengan penelitian yang dilakukan oleh (Elvivin et al., 2016) terhadap nelayan suku Bajo di Pulau Tasipi Kabupaten Muna Barat dimana konsumsi makanan tinggi natrium memiliki pengaruh yang signifikan $(\mathrm{OR}=5,271 ; \mathrm{p}=0.04)$. Natrium adalah kation utama dalam cairan ektraseluler. $35 \%-40 \%$ natrium ada di dalam kerangka tubuh (Almatsier, 2019).

Penelitian ini sejalan dengan penelitian yang dilakukan oleh (Artiyaningrum, 2001) ditemukan bahwa terdapat pengaruh yang signifikan $(\mathrm{OR}=4,173 \mathrm{p}=0,001)$ antara mengonsumsi garam dengan kejadian hipertensi. Penelitian ini juga sejalan dengan penelitian (Mahmudah et al., 2015) pada penderita hipertensi di Depok diperoleh hubungan signifikan (OR 4,629 CI 157-13,635 p=0,045) antara pola makan dengan mengonsumsi makanan berlemak dengan kejadian hipertensi, Konsumsi makanan memberikan pengaruh terbesar terhadap kejadian hipertensi terutamanya makanan beresiko. Makanan beresiko adalah makan yang dapat menimblukan risiko penyakit degeneratif. Makanan pencetus timbulnya hipertensi seperti diantaranya makanan manis, sasin, penyedap, makanan yang diawetkan, makanan berlemak, jeroan dan berkafein. Konsumsi jeroan dapat menimbulkan terjadinya hipertensi karena adanya kandungan lemak jenuh pada jeroan tersebut (Whitehorn et al., 2016).

Penelitian ini dilakukan pada nelayan yang bertempat tinggal di Kota Medan dimana mayoritas suku dan etnis yang ada bagi masyarakat pesisir pantai adalah suku melayu. Kebiasaan makan suku melayu dalam menggunakan dan menambahkan santan dalam olahan makanan sebagai citarasa yang membuat makanan terasa lebih gurih dan enak. Makanan bersantan mengandung lemak yang dibutuhkan dalam tubuh sebagai zat pelindung dan pembangun. Namun konsumsi yang secara berlebihan akan mengakibatkan timbulnya plask dalam pembuluh darah yang jika dalam panjang dikonsumsi secara rutin akan mengakibatkan hipertensi. Makanan bersantan mengandung kolesterol yang banyak terdapat dalam LDL yang akan menumpuk pada dinding pembuluh darah yang menyebabkan plak yang bercampur dengan protein yang ditutupin oleh sel otot dan kalsium 
yang berkembang menjadi arterosklerosis dan terjadinya penyempitan pembuluh darah sehingga aliran darah dalam pembuluh koroner naik dan memicu terjadinya hipertensi (Almatsier, 2019).

Penelitian yang dilakukan oleh (Simatupang \& Siregar, 2017)bahwa terdapat hubungan anatara tingkat konsumsi makanan bersantan dengan kejadian hipertensi pada suku melayu dengan penyakit hipertensi di Desa Pertumbukan Kecamatan Stabat Kabupaten Langkat.

Untuk mencegah kejadian hipertensi Joint National Comitte on Prevention, Detection, Evaluation and Treatment of High Blood Pressure (JNC7) merekomendasikan modifikasi gaya hidup. Program penurunan berat badan, mengurangi sodium dalam makanan, aktifitas fisisk secara teratur minimal 30 menit hampir setiap hari, mengonsumsi banyak sayuran dan buah-buahan, mengonsumsi produk susu rendah lemak (National Institutes of Health, 2013).

Perilaku makan sehat dapat dilakukan dengan cara mengurangi sodium dalam makanan, mengurangi asupan alkohol, dan aktifitas fisik secara teratur untuk mecapai berat badan ideal dalam rangka menurunkan hipertensi (Haung et al., 2008).

Kebiasaan merokok pada nelayan merupakan gaya hidup yang telah menjadi kebiasaan, merokok bagi nelayan berguna dalam menghangatkan badan saat berada di laut. Merokok yang bersifat adiktif/kecanduan menjadikan kebiasaan merokok tidak saja dilakukan saat bekerja di atas laut namun juga pada waktu tidak bekerja di atas laut.

Hasil penelitian ini diperoleh bahwa ada hubungan signifikan antara variabel merokok dengan kejadian hipertensi pada nelayan di Kota Medan dengan nilai OR sebesar 6,989 (95\%CI 2,283-21,395 $p=0,001)$. Dari hasil wawancara ini diperoleh informasi bahwa hampir lebih dari setengah responden telah merokok selama 10 tahun atau lebih, dengan jenis rokok yang palig banyak dihisap adalah jenis rokok filter dengan jumlah rokok paling banyak dihisap paling banyak $>10$ batang/hari.

Penelitian ini sejalan dengan penelitian yang dilakukan oleh (Setyanda et al., 2015) yang menunjukan adanya hubungan kebiasaan merokok dengan kejadian hipertensi hal tersebut dikarenakan responden yang memiliki kebiasaan merokok lebih banyak dibandingkan dengan yang tidak merokok dimana lebih dari setengah responden memiliki kebiasaan merokok. Laki-laki lebih beresiko menderita hipertensi daripada wanita dimana hal tersebut disebabkan oleh perilaku yang tidak sehat seperti diantaranya merokok, mengonsumsi alkohol, stress dan status pekerjaannya (Armilawaty \& Amirudin, 2007).

Penelitian ini sejalan dengan penelitian yang dilakukan oleh (Elvivin et al., 2016) terhadap nelayan suku Bajo di Pulau Tasipi Kabupaten Muna Barat dimana merokok memiliki pengaruh yang signifikan merokok (OR $=6,750 \mathrm{p}=0.00)$. Nikotin yang terdapoat di dalam rokok. Penelitian ini juga sejalan dengan penelitin (Arda \& Mustapa, 2018) di Puskesmas Motolohu Kabupaten Pohuwato ditemukan bahwa merokok memiliki pengaruh yang sigifikan terhadap kejadian hupertensi $(\mathrm{OR}=2,555)$

Menghisap rokok memiliki pengaruh besar terhadap hipertensi. CO yang berasal dari asap rokok membuat 
pembuluh darah mengalami "kramp" yang mengakibatkan tekanan darah semakin meningkat, dinding pembuluh darah pun menjadi robek. Proses inflamasi terjadinya jumlah protein $\mathrm{C}$ reaktif dan agen inflamasi alami megakibatka difungsi endotelium, kerusakan pembuluh darah sehingga terjadi pembetukan plak di dinding arteri, akibatnya darah yang akan mengalir di saluran pembuluh darah menjadi terhambat akibat arteri kaku dan mengalami plak tersebut sehingga dibutuhkan dorongan yang kuat agar darah bisa mengalir yang berujung pada kenaikan tekanan darah dan hipertensi.

Pengeluaran untuk rokok sangat merugikan bagi seseorang dengan pendapat yang rendah dan menengah hal ini dikarenakan merokok menimbulkan sensasi yang sementara bagi perokok dan konsumsi rokok jangka waktu tertentu akan menjadi beban ekonomi bagi individu, rumah tangga dan negara. Pengeluaran yang dilakukan untuk kebiasaan merokok dapat mengabaikan kebutuhan lain yang lebih penting seperti ketersediaan makanan yang sehat, pendidikan dan kesehatan (Aulia \& Ayu, 2018).

Merokok adalah salah satu kebiasaan yang lazim ditemukan dalam kehidupan sehari-hari. Sangat mudah menemukan orang yang merokok baik laki-laki ataupun perempuan, baik tua ataupun muda, baik kaya ataupun miskin tanpa terkecuali. Walaupun dari segi kesehatan tidak ada satupun manfaat yang diperoleh dari merokok (Syahrin et al., 2017).

Dalam penelitian ini responden yaitu nelayan telah memiliki kebiasaan mengonsumsi kopi lebih dari 10 tahun dengan jumlah cangkir kopi mayoritas sebanyak $\geq 3$ cangkir kopi yang dikonsumsi sebanyak 3 kali dalam seharinya. Kebiasaan mengonsumsi kopi merupakan salah satu cara menahan kantuk dan menghangatkan tubuh saat bekerja di laut. Hasil penelitian ini diperoleh bahwa tidak ada hubungan antara variabel minum kopi dengan kejadian hipertensi dengan nilai $\mathrm{OR}=0,764(95 \% \mathrm{CI} \quad 0,276-2,119$ $p=0,606$ ) artinya variabel minum kopi bukan faktor resiko/tidak berpegaruh terhadap kejadian hipertensi pada nelayan di Kota Medan.

Hasil penelitian mayoritas nelayan yang minum kopi juga memiiki kebiasaan merokok yaitu sebanyak 71 orang (81\%) sehingga kesehariannya para nelayan yang merokok juga memilih minum kopi sebagai pendamping konsumsi utamanya. Hipertensi yang terjadi pada nelayan yang minum kopi lebih dikarenakan akibat merokok yang merupakan perilaku yang memengaruhi hipertensi dimana minum kopi tidak lepas dari perilaku merokok di kehidupan sehari-harinya. Selain itu terdapat faktor lain yang memengaruhi kejadian hipertensi pada nelayan yaitu umur dan pola makan nelayan yang berisiko terhadap kejadian hipertensi.

Penelitian ini sejalan dengan penelitian (Oktaviarini et al., 2019) bahwa tidak ada hubungan antara minum kopi dengan kejadian hipertensi. Tubuh memiliki regulasi hormon kompleks yang bertugas menjaga tekanan darah yang dapat menyebabkan toleransi tubuh terdapat paparan kafein pada kopi, Secara humoral dan hemodinamik, kertika paparan kafein itu terjadi secara terus menerus. Selain memiliki kandungan yang bersifat meningkatkan tekanan darah, kopi mengandung substansi yang bersifat menurunkan tekanan 
darah yaitu polifenol dan kalium. Kopi instan mnengandung serat larut air yang tinggi dan dihubungkan dengan kandungan polifenol (antioksidan).

Kandungan kalium dalam kopi diketahui tinggi. Polifenol menghambat terjadi arterogenesis dan memperbaiki fungsi vaskuler. Kalium menurunkan tekanan darah sistolik dan diastolik dengan menghambat pelepasan renin sehingga terjadi peningkatan ekskresi natrium dan air. Hal tersebut menyebabkan terjadi penureunan volume plasma, curah jantung dan tekanan perifer sehingga tekanan darah akan turun. Polifenol dan kalium dapat menyeimbangkan efek kafein. Konsumsi kopi pada dosis tertentu, cenderung menurunkan tekanan darah hal ini disebakan oleh kandungan kalium pada kopi yang tinggi.

Hasil penelitian ini sejalan dengan penelitian (Enggarwati \& Dahlia, 2014) dimana tidak terdapat hubungan anatar konsumsi kopi dengan kejadian hipertensi. Konsumsi kafein dan tingkat asupan kafein tidak memiliki kontribusi terhadap tekanan darah tinggi sebab efek kafein akan menghilang dala 5 hari. Berkaitan dengan waktu paruh kafein yang berkisar 4-5 jam maka efek kafein dalam tubuh akan menghilang setelah periode waktu paruh tersebut (Bealer, 2010).

Durasi tidur pendek atau keadaan dimana sesorang tidak mendapatkan tidur yang cukup (sleep restriction) dapat menyebabkan meningkatnya tekanan darah. Durasi Tidur diyakini sebabagi salah satu faktor yang dapat mencetuskan terjadinya hipertensi selain faktor usia dan gaya hidup (Bartholomew et al., 2006).

Hasil penelitian ini diperoleh bahwa tidak ada hubungan antara durasi tidur dengan kejadian hipertensi dengan nilai $\mathrm{OR}=2,293(95 \% \mathrm{CI} 0,790$ $6,656 p=0,129)$ artinya variabel durasi tidur bukan faktor resiko/tidak berpegaruh terhadap kejadian hipertensi pada nelayan di Kota Medan. Berdasarkan hasil wawancara pada responden yaitu nelayan mayoritas durasi tidur $<8$ jam perharinya dengan jam tidur berada pada tidur pukul 11 malam dan akan bangun jam 4 pagi dan tidur pada pukul 3 pagi dan akan bangun jam 9 pagi.

Penelitian ini sejalan dengan penelitian yang dilakukan oleh (Aad et al., 2011) bahwa tidak ada hubungan antara pola tidur dengan hipertensi dimanan beberapa orang yang mengalami hipertensi pada penelitian tersebut lebih disebabkan oleh pengaruh umur terhadap kejadian hipertensi.

Durasi tidur yang pendek merupakan salah satu penyebab hipertensi namun dalam penelitian ini berbagai faktor yang lebih dominan dalam memengaruhi kejadian hipertensi yaitu diantaranya pola makan yang berisiko, kebiasaan merokok dan umur nelayan yang semakin tua menjadi penyebab yang berdampak tingginya angka kejadian hipertensi pada nelayan

Penelitian ini sejalan dengan penelitian yang dilakukan oleh (Rusmawati, 2015) Terhadap pasien hipertensi di RSU Dr. Saiful Anwar Malang ditemukan tidak adanya pengaruh signifikan $(\mathrm{p}=0,65 \mathrm{p}=0,79)$ antara durasi tidur dengan kejadian hipertensi.

Durasi tidur $<8$ jam/hari yang dilakukan oleh nelayan juga salah satu pengaruh dari kebiasaan konsumsi kopi dimana dari hasil penelitian terdapat 73 orang nelayan $(86 \%)$ yang memiliki 
kebiasaan minum kopi dengan durasi tidur $>8$ jam/harinya. Kafein yang terkandung di dalam kopi memiliki keuntungan dan manfaat bagi tubuh jika diminum secara tidak berlebihan dimana membantu sebagai salah satu perangsang dalam melakukan berbagai aktifitas, menghindari kantuk dan meningkatkan daya pikir serta panca indera, mengurangi rasa lelah dan mempercepat daya pikir (Martiani \& Lelyana, 2012).

Nelayan memiliki kebiasaan mengkonsumsi kopi saat melaut, hal ini membantu mereka agar tidak mengantuk dan tidak cepat merasa lelah dalam berkatifitas selama masa melaut di atas kapal dalam mencari hasil tangkapan di laut. Aktifitas minum kopi yang mengandung kafein tersebut menjadi kebiasaan pada nelayan meski mereka tidak sedang melaut, jumlah yang dikonsumsi oleh nelayan per harinya bervariasi

Waktu yang paling optimal untuk mulai tidur di malam hari adalah jam 10 malam, selain berguna untuk mengumpulkan tenaga dan energi juga sangat baik untuk vitalitas tubuh dan meningkatkan mood positif di pagi hari. Kebutuhan tidur seseorang berbeda-beda untuk umur 18-40 tahun durasi tidur adalah 8 jam/hari, untuk umur 41-60 tahun durasi tidur yang dibutuhkan adalah $7 \mathrm{jam} / \mathrm{hari}$ dan untuk umur di atas 60 tahun durasi tidur yang dibutuhkan adalah 6 jam/hari (Hidayat \& Meiranto, 2014).

\section{Kesimpulan}

Kesimpulam yang diperoleh dari hasil penelitian ini yaitu terdapat pengaruh yang signifikan antara penghasilan dan gaya hidup (pola makan dan kebiasaaan merokok) terhadap kejadian hipertensi pada nelayan di kota Medan. Hasil regresi logistik berganda menunjukkan variabel yang memiliki pengaruh paling dominan dengan kejadian hipertensi pada nelayan adalah pola makan. Risiko terjadinya hipertensi pada nelayan dengan pola makan yang berisiko meningkat 6,972 kali lebih besar dibandingkan nelayan yang pola makannya tidak berisiko.

\section{BIBLIOGRAFI}

Aad, G., Abbott, B., Abdallah, J., Abdelalim, A. A., Abdesselam, A., Abi, B., Abolins, M., Abramowicz, H., Abreu, H., \& Acerbi, E. (2011). Measurement Of The Inclusive Isolated Prompt Photon Cross Section In P P Collisions At $\mathrm{S}=7 \mathrm{Tev}$ With The Atlas Detector. Physical Review D, 83(5), 52005.

Almatsier, S. (2019). Prinsip Dasar Ilmu Gizi.

Arda, Z. A., \& Mustapa, M. (2018). Hipertensi Dan Faktor Risikonya Di Puskesmas Motolohu Kabupaten Pohuwato. Gorontalo Journal Of Public Health, 1(1), 32-38.

Armilawaty, A. H., \& Amirudin, R. (2007). Hipertensi Dan Faktor Risikonya Dalam Kajian Epidemiologi. Bagian Epidemiologi Fkm Unhas.

Artiyaningrum, B. (2001). Faktor-Faktor Yang Berhubungan Dengan Kejadian Hipertensi Tidak Terkendali Pada Penderita Yang Melakukan Pemeriksaan Rutin Di Puskesmas Kedungmundu Kota Semarang Tahun 2014. Universitas Negeri Semarang.

Aulia, D., \& Ayu, S. F. (2018). Media Promosi Perilaku Hidup Bersih Dan Sehat (Phbs) Di Kawasan Wisata Danau Toba. Abdimas Talenta: Jurnal Pengabdian Kepada Masyarakat, 3(1), 68-71.

Bartholomew, L. K., Parcel, G. S., Kok, G., Gottlieb, N. H., Schaalma, H. C., Markham, C. C., Tyrrell, S. C., Shegog, 
R. C., Fernández, M. C., \& Mullen, P. D. C. (2006). Planning Health Promotion Programs: An Intervention Mapping Approach. Jossey-Bass.

Bealer, B. K. (2010). The Miracle Of Caffeine: Manfaat Tak Terduga Kafein Berdasarkan Penelitian Paling Mutakhir. Pt Mizan Publika.

Eberhardt, L., Gaberdiel, M. R., Gopakumar, R., \& Li, W. (2017). Bps Spectrum On Ads $3 \times$ S $3 \times$ S $3 \times$ S. Journal Of High Energy Physics, 2017(3), 124.

Elvivin, E., Lestari, H., \& Ibrahim, K. (2016). Analisis Faktor Risiko Kebiasaan Mengkonsumsi Garam, Alkohol, Kebiasaan Merokok Dan Minum Kopi Terhadap Kejadian Dipertensi Pada Nelayan Suku Bajo Di Pulau Tasipi Kabupaten Muna Barat Tahun 2015. (Jurnal Ilmiah Mahasiswa Kesehatan Masyarakat), 1(3).

Enggarwati, P., \& Dahlia, D. (2014). Tekanan Darah Berdasarkan Pola Konsumsi Kopi Civitas Akademika Fakultas Ilmu Keperawatan Universitas Indonesia. Depok: Fik Ui.[Cited 2017 Maret 25].

Fatma, Y. (2010). Pola Konsumsi Dan Gaya Hidup Sebagai Faktor Resiko Terjadinya Hipertensi Pada Nelayan Di Kabupaten Bintan Provinsi Kepulauan Riau Tahun 2009. Universitas Gadjah Mada.

Haung, Y. M., Li, H., Huang, X. J., Hu, Y. C., \& $\mathrm{Hu}, \mathrm{Y} .(2008)$. Advances Of BioEthylene. Chin J Bioprocess Eng, 6, 16.

Hidayat, M. A., \& Meiranto, W. (2014). Prediksi Financial Distress Perusahaan Manufaktur Di Indonesia (Studi Empiris Pada Perusahaan Manufaktur Yang Terdaftar Di Bursa Efek Indonesia Periode 2008-2012). Fakultas Ekonomika Dan Bisnis.

Husain, I. A., \& Rohmah, P. (2020). Strategi Pt. Gojek Dalam Mengembangkan
Transportasi Publik Berbasis Online Di Indonesia. Jurnal Syntax Transformation, 1(3), 14-23.

Hussain, T., Tan, B., Yin, Y., Blachier, F., Tossou, M. C. B., \& Rahu, N. (2016). Oxidative Stress And Inflammation: What Polyphenols Can Do For Us? Oxidative Medicine And Cellular Longevity, 2016.

Kemenkes Ri. (2016). Profil Kesehatan Indonesia Tahun 2015. In Jakarta: Kementerian Kesehatan Republik Indonesia.

Mahazan, A. M., Nurhafizah, S., Rozita, A., Aishah, H. S., Azdi, W. R. W. M. F., Rumaizuddin, G. M., Yuseri, A., Rosmizi, A. R. M., Muhammad, H., \& Azhar, I. R. M. (2015). Islamic Leadership And Maqasid Al-Shari'ah: Reinvestigating The Dimensions Of Islamic Leadership Inventory (Ili) Via Content Analysis Procedures. International E-Journal Of Advances In Social Sciences, 1(2), 153-162.

Mahmudah, S., Maryusman, T., Arini, F. A., \& Malkan, I. (2015). Hubungan Gaya Hidup Dan Pola Makan Dengan Kejadian Hipertensi Pada Lansia Di Kelurahan Sawangan Baru Kota Depok Tahun 2015. Biomedika, 7(2).

Martiani, A., \& Lelyana, R. (2012). Faktor Risiko Hipertensi Ditinjau Dari Kebiasaan Minum Kopi (Studi Kasus Di Wilayah Kerja Puskesmas Ungaran Pada Bulan Januari-Februari 2012). Diponegoro University.

Medan, D. K. (2016). Profil Kesehatan Kota Medan. In Medan. Dinas Kesehatan Kota Medan.

National Institutes Of Health. (2013). National Institutes Of Health State-OfThe-Science Conference Statement: Symptom Management In Cancer: Pain, Depression, And Fatigue, July 15-17, 2002. Journal Of The National Cancer Institute, 95(15), 1110-1117. 
Ningsih, D., \& Kurniawan, P. H. (2019). Strategi Afiliasi Bisnis: Suatu Model Pemilihan Channel Penjualan Dan Pengelolaan Hotel Non Jaringan Di Kota Batam. Prosiding Seminar Nasional Ilmu Sosial Dan Teknologi (Snistek), 2, 55-60.

Notoatmodjo, S. (2012). Metodologi Penelitian Kesehatan.

Oktaviarini, E., Hadisaputro, S., Suwondo, A., \& Setyawan, H. (2019). Beberapa Faktor Yang Berisiko Terhadap Hipertensi Pada Pegawai Di Wilayah Perimeter Pelabuhan (Studi Kasus Kontrol Di Kantor Kesehatan Pelabuhan Kelas Ii Semarang). Jurnal Epidemiologi Kesehatan Komunitas, 4(1), 35-44.

Organization, W. H. (2015). Who Report On Global Surveillance Of Epidemic-Prone Infectious Diseases: Dengue And Dengue Haemorrhagic Fever, 2014 [Cited 2014 Jul 21].

Roshifanni, S. (2016). Risiko Hipertensi Pada Orang Dengan Pola Tidur Buruk. Jurnal Berkala Epidemiologi, 4(3), 408-419.

Rusliafa, J., Amiruddin, R., \& Noor, N. B. (2014). Komparatif Kejadian Hipertensipada Wilayah Pesisirpantai Dan Pegunungan Di Kota Kendari Tahun 2014. Mkmi, 1, 1-13.

Rusmawati, E. (2015). Pengaruh Durasi Tidur Dan Gangguan Tidur Terhadap Tekanan Darah Pada Pasien Hipertensi Di Poliklinik Jantung Rumah Sakit Umum Dr. Saiful Anwar Malang. Universitas Brawijaya.

Sastroasmoro, S., \& Ismael, S. (2011). Dasar-
Dasar Metodologi Penelitian Klinis. In Jakarta: Sagung Seto (Vol. 55).

Setyanda, Y. O. G., Sulastri, D., \& Lestari, Y. (2015). Hubungan Merokok Dengan Kejadian Hipertensi Pada Laki-Laki Usia 35-65 Tahun Di Kota Padang. Jurnal Kesehatan Andalas, 4(2).

Simatupang, B. S. A., \& Siregar, H. H. (2017). Korelasi Mengkonsumsi Makanan Bersantan Pada Suku Melayu Dengan Penyakit Hypertensi Di Desa Pertumbukan Kecamatan Stabat Kabupaten Langkat.

Statistik, B. P. (2019). Data Dan Informasi Kemiskinan Kabupaten/Kota Tahun 2015. In Jakarta: Badan Pusat Statistik.

Syahrin, A., Amiruddin, A., \& Bustamam, B. (2017). Peran Guru Pendidikan Jasmani Dalam Membentuk Karakter Siswa Pada Mts Se-Banda Aceh Tahun Pelajaran 2016/2017. Jurnal Ilmiah Mahasiswa Pendidikan Jasmani, Kesehatan Dan Rekreasi, 3(2).

Whitehorn, J., Nguyen, C. V. V., Khanh, L. P., Kien, D. T. H., Quyen, N. T. H., Tran, N. T. T., Hang, N. T., Truong, N. T., Hue Tai, L. T., \& Cam Huong, N. T. (2016). Lovastatin For The Treatment Of Adult Patients With Dengue: A Randomized, Double-Blind, PlaceboControlled Trial. Clinical Infectious Diseases, 62(4), 468-476. 